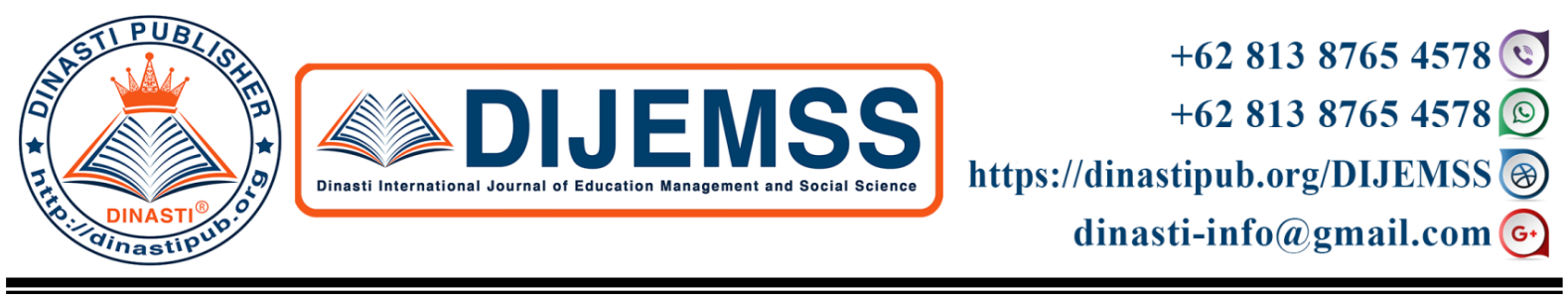

\title{
TALENT MANAGEMENT AND WORK MOTIVATION TO IMPROVE PERFORMANCE OF EMPLOYEES
}

\author{
Bella Novinda Damarasri ${ }^{1}$, Eeng Ahman ${ }^{2}$ \\ 1) Universitas Pendidikan Indoneisa, \\ ${ }^{2)}$ Universitas Pendidikan Indonesia.
}

ARTICLE INFORMATION

Received: $01^{\text {st }}$ April 2020

Revised: $20^{\text {st }}$ April 2020

Issued: $27^{\text {th }}$ April 2020

Corresponding author:

Bella novinda Damarasri

E-mail:

bellahutagalung03@gmail.com

eengahman@upi.edu

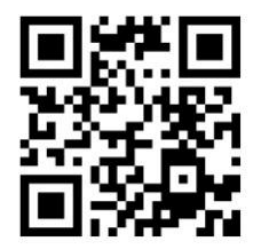

DOI:10.31933/DIJEMSS
Abstract: Purpose - To find out (1) An explanation of employee performance, (2) describing Talent Management, (3) an explanation of Work Motivation, (4) the effect of Talent Management and Work Motivation on Employee Performance. Design / Methodology / Approach - This research was conducted on a sample without random, using descriptive and verification approaches with explanatory research methods and data analysis techniques using multiple linear regression. Finding Talent Management and Work Motivation affect to Employee Performance Originality - The difference is determined in the independent variables, the object and method of the study, the population and research sample, the research period, the measurement instrument and the results of the research, as well as the theoretical sources based on international journals and books and research results.

Keywords: Talent Management, Work Motivation, Employee Performance.

\section{INTRODUCTION}

Facing the era of Industrial 4.0 the role of human beings becomes an organizational success in achieving goals (Marin-Garcia \& Zarate-Martinez, 2017).) Without the role of human resources itself the goals of the organization cannot realize conceptual plans. (Shalhoub et al., 2016) and as an object of driving the organization's direction to stay competitive (Govindarajan dan Fisher 1990). The existence of qualified human resources can be a complement to other functional strategies, so as to make the company much more confident in facing business competition and as a profit-producing company.(Wahyono, 2018)

The main problem of human resource management is focuses on employee performance, companies must implement effective and comprehensive strategies (Linz 2012). Employee performance must have proportional standards that encompass the ability of 
human resources in the company with the expectation that work targets can be realized on time so that it will be in accordance with company goals (Goksel et al., 2017). Research (Octavia, Hanna Viany \& Susilo, 2018) stated that excellent performance gets a percentage between $86 \%-100 \%$, while good criteria get a percentage of $71 \%-85 \%$ and the medium category gets a percentage of $57 \%-70 \%$. And the low and very low categories are at the percentage of $31 \%-56 \%$ and below $27 \%$.

The percentage level shows the need for managing human resources in a company to balance the needs of employees and the ability of the company (Sonny, 2012) The quality and quantity of employee work is a very important element in improving the performance of a company (Sholehatusya'diah, 2017). Through employee performance appraisal must be done by the company regularly, because with performance appraisal, an organization or company can find out how much an employee contributes to their company. The problem that is still a research issue since 1955 until now regarding the problem of employee performance, both service companies, manufacturing or government agencies around the world that has decreased (Brayfield \& Crockett, 1955).

Employee performance problems are considered to have urgency because employees are the driving force of a company, which means ignoring this problem, so it has the potential to damage the company's system (Hakim, 2013: 115) employees with low performance levels, and lack of ability to use the equipment and technology that is very possible employees produce poor performance and not in accordance with company goals and targets (García-Pinillos, et al, 2015: 6). On the other hand, employees with low work experience are considered to have no qualifications, which only becomes a burden on the company (Ulku \& Pamukcu, 2015: 12), which can eventually lead to termination of employment with the employee.

Another fact explains that many companies are already accustomed to using technology systems in company operations so that employees need to improve their competence in order to compensate for changes in existing conditions (Taormina, 2011: 12). Another problem of employee performance in 2017-2019 is that employees have a low mentality so they decide to resign from the company because they feel the company's demands are considered quite high (DeWeese et al, 2019:. 13).

Table 1.1

Result of Assessment of Education Performance Smkn 3 Baleendah

\begin{tabular}{ccccccc}
\hline Nilai & Kategori & \multicolumn{5}{c}{ Tahun } \\
\cline { 3 - 7 } & Penilaian & $\mathbf{2 0 1 4}$ & $\mathbf{2 0 1 5}$ & $\mathbf{2 0 1 6}$ & $\mathbf{2 0 1 7}$ & $\mathbf{2 0 1 8}$ \\
\hline $86-100$ & $\begin{array}{c}\text { Sangat } \\
\text { Baik }\end{array}$ & 50 & 50 & 30 & 20 & 17 \\
& Baik & 35 & 30 & 35 & 33 & 33 \\
\hline $71-85$ & Cukup & 15 & 20 & 20 & 27 & 25 \\
\hline $56-70$ & & & 15 & 15 & 20 \\
\hline $41-55$ & $\begin{array}{c}\text { Kurang } \\
\text { Baik }\end{array}$ & & & & \\
\hline$<40$ & Buruk & & & 5 & 5 \\
\hline \multicolumn{5}{c}{ Source: Survey result at SMKN 3 Baleendaah } \\
\hline
\end{tabular}

The results of the assessment performance education staff at SMKN 3 Baleendah in 2014 and 2015 experienced a very good percentage of employees moving and the consistency rate was $50 \%$ at a conditional value of 86> however, in 2016 to 2018 the number of employees experiencing unfavorable conduct conditions was corrected by an average of 
$16,7 \&$. At a conditional value $<40$ there are employees who experience a drastic decrease in performance of around $10 \%$ of the total employees.

The company should make the phenomenon of the decline in employee performance as a barometer in making policies more progressive for the progress of the company, because if left unchecked it will reduce the achievement and productivity of the company every year (Lipman, 2016). This problem cannot be ignored because it will have an impact on the company's progress (Sinex \& Chapman, 2015) The impact of employee performance that does not get more attention, according to the theory explaining performance problems needs to get recognition, analyze, and converge a reality that occurs through reinforcement, expectations, actualization, social learning, work equipment, and roles in the organization (Armstrong, 2014), theory can provide an explanation that employee performance problems must be correlated to psychological and physiological improvement if both components are not given will have an impact on employee performance problems (Lipman, 2016), the company will stagnate, slow down the production process, and also weaken competition with competitors (Ulku \& Pamukcu, 2015).

\section{LITERATURE REVIEW}

It is wrong if a human ability is said to be a standard at a certain point or point (not fixed ability), because an ability of its nature will continue to develop (developing abilities). For this reason, potential energy (talent) requires generation, processing or can be called the actualization process (Mauner dalam Sheal, 2003:47). Talent management is a sequence of human resource processes in integrated organizations designed to develop and maintain productivity of the employees involved (Irmawaty dan Hamdani 2016; Silvianita dan Anjani 2016; Octavia, Hanna Viany \& Susilo 2018). Based on research conducted by The Office of Talent Management and Organizational Development (2010), defines that talent management is the arrangement of organizational human resource processes that are designed to attract, develop, motivate, and retain productive and engaged workers. Talent is not enough this is because someone who has talent but does not take the necessary action then he never gets the expected results. (Lewis dan Heckman 2006; Cappelli 2008; Collings dan Mellahi 2009; Scullion dan Collings 2011; Vaiman, Scullion, dan Collings 2012; Dries 2013 ; Schiemann 2014; Carpenter 2017) Someone who has talent but does not focus on his field then he will not be able to improve his performance. Someone who has talent but does not practice then he will not reach perfection in his work. Thus, someone who has talent needs to take appropriate actions to hone and utilize these talents to become self-strength in the work. (Collings, Scullion, \& Vaiman, 2015)

Talent Management is a management process that emerged in 1990 and continues to be used, because more and more companies are realizing that the success of their business is determined by the talents and abilities of their employees. Companies that practice Talent Management concept have used it to deal with employee retention issues. There are several dimensions that can be a supporting factor for talent management according to (Carpenter, 2017c) including, 1) Behavior, 2) Career Experience, 3) Potency, 4) Personal character quality, 5) Initiative, 6) Learner's soul, 7) Cooperation, and 8) Skills. In addition, the desire to act employees who can arise from within sometimes must be injected and strengthened from outside parties, in order to align motivation with employee needs (Jang, et al., 2011:4). then motivation can be the second solution to performance problems, then motivation can be the second solution to performance problems, (Tella, 2016:5)

Motivation can be defined as an individual's drive to take action because they want to do it, if the individual is motivated then the individual will make positive choices to do 
something (Veithzal. 2015:607), if the work environment is comfortable even more so if employees already have a sense of belonging to the company then the motivation will be a measure of how long a person can maintain their business, because motivation is a value that guides the principles of human life based on overall needs so that people remain consistent (Yagyagil, 2015:3), some motivation theories works with the assumption that by giving opportunities and the right stimulation, employees will work well and positively, managers need to be careful in providing reinforcement to employees. Motivational variables have two primary indicators. 1) Individual input includes an individual's increased ability, expertise, emotional control and value. 2). The work context includes the physical environment, appreciation, reinforcement, training, social norms and organizational culture. These two main factors can be indicators in resolving problems of declining company performance standards because they have motivational processes that encompass attention, direction, perseverance, and work intensity so as to result in positive work behavior, especially in providing solutions to the problem of timeliness of employees in completing work (Kinicki, 2014:330). It very relevant if enforced in the company because motivation does not only talk about money but also about honor, appreciation, physical activities that require a sense of security (Sharma et al., 2015:5).

Speaking of motivation, Herzberg's theory of (Kiruja, 2013) contained four dimensions of motivation, namely the motivators and hygiene factors, in motivators there are 1) achievement, 2) recognition, 3) job interest, 4) responsibility, and advancement. Whereas the dimensions of hygiene factors appear more, including 1) salary and benefits, 2) working conditions, 3) company policy, 4) status, 5) job security, 6) supervision and autonomy, 7) office life, and 8) personal life.

The development of the company will be far more optimal if all directors are able to provide intensive motivation (Kiruja, 2015), so that employees will experience accelerated performance in order to achieve company goals. Performance is able to show whether employees have met the desired target of employees, both in terms of quality and quantity, in performance are also able to make an assessment because in a management organization without performance appraisal, the company does not know the next step for company progress (Veithzal, et al, 2015:405). Performance is a result of work achieved by a person in carrying out the tasks assigned to him based on skill, experience and sincerity and time of measurement (Albrecht, et,al 2015:3). Employee performance can be measured through 1). Punctuality to show dedication to the company, 2). Achieved targets to prove the contribution made to the company, 3). Job understanding shows responsive ability, responsiveness, 4). Understanding operational standards show employees who are guided by company procedures 5). Submitting ideas and ideas shows a dynamic employee who can be a solution provider, 6). Cooperation, employees must be able to work together with other employees in completing a job 7). Responsibility, shows a loyalty for the company and 8). In the way of leadership, employees must be able to lead other colleagues when working with teams (Zachary, 2017:237).

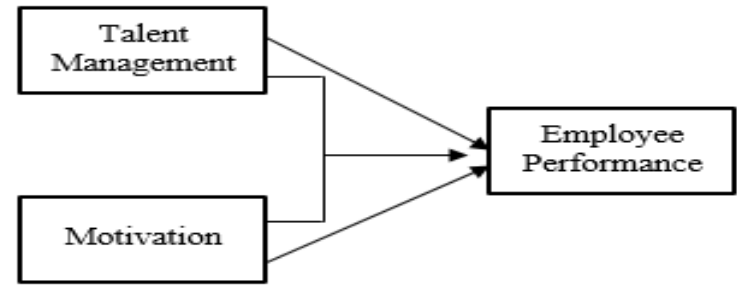

PICTURE 1

RESEARCH PARADIGM

(Tella, 2016:5); Albrecht, et,al 2015:3; Veithzal, et al, 2015:405). 


\section{RESEARCH METHODS}

This research was conducted to determine the effect of Talent Management and Motivation on Employee Performance. The independent variable in this research is Talent Management and Motivation. while the dependent variable (dependent variable) in this research is Employee Performance.

This research was conducted at SMKN 3 Baleendah. The type of research used is descriptive and verification. Based on the type of research, the method used in this research is explanatory research which aims to test the hypothesis between independent variables with the dependent variable. Data collection techniques used are literature study and documentation.

\section{FINDINGS AND DISCUSSION}

Based on the results of calculations using multiple linear regression between the effect of talent management on employee performance of 0.984 and the influence of motivation on employee performance of 1,178 .

Table 1.2

Output data analisis memakai aplikasi SPSS

\begin{tabular}{|l|c|r|r|c|}
\hline Model & $\mathrm{R}$ & $\mathrm{R}$ Square & \multicolumn{1}{|c|}{$\begin{array}{c}\text { Adjusted R } \\
\text { Square }\end{array}$} & $\begin{array}{c}\text { Std. Error of the } \\
\text { Estimate }\end{array}$ \\
\hline 1 & $.740^{\mathrm{a}}$ & .548 & .534 & \multicolumn{1}{c|}{7.648} \\
\hline
\end{tabular}

a. Predictors: (Constant), Motivasi (X2), Talent Management (X1)

\begin{tabular}{|c|c|c|c|c|c|c|}
\hline \multicolumn{7}{|c|}{ ANOVA $^{a}$} \\
\hline & & Sum of Squares & df & Mean Square & $\mathrm{F}$ & Sig. \\
\hline \multirow[t]{3}{*}{1} & Regression & 4814.078 & 2 & 2407.039 & 41.150 & $.000^{\mathrm{b}}$ \\
\hline & Residual & 3977.584 & 68 & 58.494 & & \\
\hline & Total & 8791.662 & 70 & & & \\
\hline
\end{tabular}

a. Dependent Variable: Kinerja $(Y)$

b. Predictors: (Constant), Motivasi (X2), Talent Management (X1)

\begin{tabular}{|c|c|c|c|c|c|c|}
\hline \multicolumn{7}{|c|}{ Coefficients $^{a}$} \\
\hline \multirow{2}{*}{\multicolumn{2}{|c|}{ Model }} & \multicolumn{2}{|c|}{ Unstandardized Coefficients } & $\begin{array}{c}\text { Standardized } \\
\text { Coefficients }\end{array}$ & \multirow[b]{2}{*}{$t$} & \multirow[b]{2}{*}{ Sig. } \\
\hline & & $\mathrm{B}$ & Std. Error & Beta & & \\
\hline \multirow[t]{3}{*}{1} & (Constant) & 14.051 & 8.059 & & 1.754 & .086 \\
\hline & Talent Management (X1) & .098 & .031 & .287 & 3.169 & .002 \\
\hline & Motivasi (X2) & 1.178 & .130 & .817 & 9.035 & .000 \\
\hline
\end{tabular}

a. Dependent Variable: Kinerja (Y)

Hypothesis testing in this study is to use the F test and $t$ test. Based on the results of the $F$ test to simultaneously test the hypothesis, the $F_{\text {count }}$ value of 41,150 is obtained for talent management and motivation simultaneously affect to performance employee. Based on 
$\mathrm{t}$ test for talent management and motivation with a significance level $\alpha=0.05$, a $\mathrm{t}_{\text {count }}$ of 3,169 and $t_{\text {table }} 1,99547$. So the results of sig. 3,169>1,99547 so can be concluded that talent management effects performance employee. Obtained by $t_{\text {count }} 9,035$ for Motivation. Then a decision can be taken that motivation affects performance employee.

This means that there is a significant influence of talent management on employee performance. In accordance with the results of research conducted by (Vaiman, Scullion, Collins 2012), (Dries, 2013), (Schiemann, 2014) dan (Carpenter, 2017) which states that talent management influences employee performance.

There is a significant influence of motivation on employee performance. This is consistent with research conducted by (Balkin, 2017).(Zachary, 2017). and (Sakamoto, 2017) which states that motivation will affect employee performance.

\section{CONCLUSION AND RECOMMENDATIONS}

Based on the discussion of theory, research results, and linear regression analysis testing conducted on the effect of talent management and work motivation on employee performance can be concluded as follows:

1. The description of talent management is good enough. This can be seen from the dimension of talent management representatives of the organization.

2. Description of motivation is good enough. This can be seen from the representative dimension of motivation.

3. The employee's performance description is good enough. This can be seen from the increasing dimensions of work output.

4. Based on the results of the research states that, talent management affects employee performance. shows that the better the talent management of the company, the better the performance of employees.

5. Based on the results of the research states that, work motivation has an effect on employee performance. shows that better work motivation will also result in better performance for the company.

6. Based on the results of the research states that, talent management and motivation have a combined (simultaneous) effect on employee performance. shows that the better the talent management and motivation the company provides to employees, the better the performance will be.

\section{REFERENCE}

Albrecht, S. L., Bakker, A. B., Gruman, J. A, Macey, W. H., \& Saks, A. M. (2015). Journal Of Organizational Effectiveness: People And Performance Article Information: to Cite this Document : Vol. 2 Iss(Performnace), 244-266.

Armstrong, S. (2014). Human Resource Management Practice (13th Ed.; Michael Armstrong, Ed.). London: Kogan Page Limited.

Atika Jauharia Hatta Dan Bambang. (2012). The Company Fundamental Factors and Systematic Risk in Increasing Stock Price. Journal of Economic, Business and Accountancy Ventura, 15(2), 245-256.

Balkin, D. (2017). Managing Human Resource (7th Editio; Pearson, Ed.). Https://Doi.Org/19.1007/978-1-84996-269-9 
Brayfield, A. H., \& Crockett, W. H. (1955). Employee Attitudes and Employee Performance. Psychological Bulletin. Https://Doi.Org/10.1037/H0045899

Cappelli, P. (2008). Talent Management for the Twenty-First Century. Harvard Business Review.

Carpenter. (2017a). Influence of Talent Management and Motivation to Employee Performance. IJOM, 4(2).

Carpenter, H. L. (2017b). Talent Management. in The Nonprofit Human Resource Management Handbook: From Theory to Practice. Https://Doi.Org/10.4324/9781315181585

Carpenter, H. L. (2017c). Talent Management. in The Nonprofit Human Resource Management Handbook: From Theory to Practice. Https://Doi.Org/10.4324/9781315181585

Collings, D. G., \& Mellahi, K. (2009). Strategic Talent Management: a Review and Research Agenda. Human Resource Management Review. Https://Doi.Org/10.1016/J.Hrmr.2009.04.001

Collings, D. G., Scullion, H., \& Vaiman, V. (2015). Talent Management: Progress and Prospects. Human Resource Ranagement Review. Https://Doi.Org/10.1016/J.Hrmr.2015.04.005

Deweese, B., Hornsby, G., Stone, M., \& Stone, M. H. (2015). The Training Process: Planning For Strength-Power Training In Track and Field. Part 2: Practical and Applied Aspects. Journal Of Sport and Health Science, (October). Https://Doi.Org/10.1016/J.Jshs.2015.07.002

Dries. (2013a). Influence Talent Management and Motivation to Employee Performance in Industrial Firm. IJOM, 39(2), 141-148.

Dries, N. (2013b). The Psychology Of Talent Management: A Review And Research Agenda. Human Resource Ranagement Review. Https://Doi.Org/10.1016/J.Hrmr.2013.05.001

García-Pinillos, F., Párraga-Montilla, J. A., Soto-Hermoso, V. M., \& Latorre-Román, P. A. (2015). Changes In Balance Ability, Power Output, and Stretch-Shortening Cycle Utilisation After Two High-Intensity Intermittent Training Protocols in Endurance Runners. Journal Of Sport And Health Science, (September). Https://Doi.Org/10.1016/J.Jshs.2015.09.003

Goksel, A. G., Caz, C., Yazici, O. F., \& Ikizler, H. C. (2017). Examination of The Relationship Between Organizational Stress and Employee Performance : a Research on Staff Working on Provincial Directorate of Youth and Sports. 6(1), 322-329. Https://Doi.Org/10.5539/Jel.V6n1p322

Govindarajan, V., \& Fisher, J. (1990). Strategy, Control Systems, and Resource Sharing: Effects on Business-Unit Performance. Academy of Management Journal. Https://Doi.Org/10.5465/256325

Irmawaty, \& Hamdani, M. (2016). Pengaruh Talent Management terhadap Pengembangan Karir Pegawai di Universitas Terbuka. Jurnal Organisasi Dan Manajemen.

Jang, H., Kim, K., Kim, J., \& Kim, J. (2011). Labour Productivity Model for Reinforced Concrete Construction Projects. Construction Innovation, 11(1), 92-113. 
Https://Doi.Org/10.1108/14714171111104655

Kinicki, A. (2014). Encyclopedia of Human Resources Information Systems : Challenges in HRM. HRM Handbook, 4(10), 446. Https://Doi.Org/11.1276/Jel.V4n1p446

Kiruja, E. (2013). Effect of Motivation on Employee Performance in Public Middle Level Technical Training Institutions in Kenya. Managementjournal.Info.

Kiruja, E. (2015). Effect Of Motivation on Employee Performance in Public Middle Level Technical Training Institutions in Kenya. Managementjournal.Info, 2(4), 73-82.

Lewis, R. E., \& Heckman, R. J. (2006). Talent Management: a Critical Review. Human Resource Management Review. Https://Doi.Org/10.1016/J.Hrmr.2006.03.001

Linz, S. J., \& Linz, S. J. (2012). Job Satisfaction Among Russian Workers. Emerald, 24(1), 30. Https://Doi.Org/10.1108/01437720310496139

Lipman, V. (2016). Research on the Mechanism That Paternalistic Leadership Impact on Employee Performance: Organizational Justice As An Intermediary Variable. 3(4), 150-156. Https://Doi.Org/10.5923/J.Hrmr.20130304.03

Marin-Garcia, J. A., \& Zarate-Martinez, E. (2017). A Theoretical Review of Knowledge Management and Teamworking in the Organizations. International Journal of Management Science and Engineering Management, 01.

Octavia, Hanna Viany \& Susilo, H. (2018). Pengaruh Manajemen Talenta Terhadap Kinerja Karyawan (Studi Pada Karyawan PT Pertamina Geothermal Energy Area Ulubelu ). Jurnal Administrasi BISNIS (JAB).

Sakamoto, S. (2017). Beyond World Class Productivity (First Edit; Spinger, Ed.). Https://Doi.Org/10.1007/978-1-84996-269-8

Schiemann, W. A. (2014). From Talent Management to Talent Optimization. Journal Of World Business. Https://Doi.Org/10.1016/J.Jwb.2013.11.012

Scullion, H., \& Collings, D. G. (2011). Global Talent Management. in Global Talent Management. Https://Doi.Org/10.4324/9780203865682

Shalhoub, J., Giddings, C. E. B., Ferguson, H. J. M., Hornby, S. T., Khera, G., \& Fitzgerald, J. E. F. (2016). Developing Future Surgical Workforce Structures: a Review of postTraining Non-Consultant Grade Specialist Roles and The Results of a National Trainee Survey from the Association of Surgeons in Training. International Journal of Surgery (London, England), 11(8), 578-583. Https://Doi.Org/10.1016/J.Ijsu.2013.09.010

Sharma, S., Tim, U. S., Payton, M., Cohly, H., Gadia, S., Wong, J., \& Karakala, S. (2015). Contextual Motivation in Physical Activity by Means of Association Rule Mining. Egyptian Informatics Journal, 33. Https://Doi.Org/10.1016/J.Eij.2015.06.003

Sholehatusya'diah. (2017). Pengaruh Kompetensi Kerja Terhadap Kinerja Karyawan di Kantor PT. Kitadin Tenggarong Seberang Sholehatusya'diah1. Ejournal Administrasi Negara.

Silvianita, A., \& Anjani, F. (2016). Pengaruh Kompetensi Terhadap Kinerja Karyawan Dengan Motivasi Sebagai Variabel Moderator di PT.Telekomunikasi Indonesia Regional III Area Witel Bandung. Jurnal Manajemen dan Bisnis Indonesia. Https://Doi.Org/10.31843/Jmbi.V3i2.78

Sinex, J. A., \& Chapman, R. F. (2015). Hypoxic Training Methods for Improving Endurance Exercise Performance. Journal of Sport and Health Science, (October), 1-8. 
Https://Doi.Org/10.1016/J.Jshs.2015.07.005

Sonny, H. (2012). Analisis Pengaruh Pengembangan SDM Terhadap Kinerja Pegawai pada Badan Kepegawaian Daerah Kabupaten Karawang. Jurnal Manajemen.

Stephen P Robbins And Timothy. (2013). Organizational Behavior (5th Ed.). New Jersey: Pearson Education Inc.

Taormina, R. J. (2011). Organizational Socialization: The Missing Link Between Employee Needs and Organizational Culture. Journal Of Managerial Psychology, 24(7), 650-676. Https://Doi.Org/10.1108/02683940910989039

Tella, A. (2016). Work Motivation, Job Satisfaction, and Organisational Commitment of Library Personnel in Academic and Research Libraries in Oyo State ,. LPAP, 50(Motivation), 1-16.

Ulku, H., \& Pamukcu, M. T. (2015). The Impact Of R\&Amp;D And Knowledge Diffusion on the Productivity of Manufacturing Firms in Turkey. Journal of Productivity Analysis, 44(1), 79-95. Https://Doi.Org/10.1007/S11123-015-0447-X

Vaiman, Scullion, C. (2012). Imfluence Talent Management and Knowladge Management to Employee Performance. IJOM, 02 .

Vaiman, V., Scullion, H., \& Collings, D. (2012). Talent Management Decision Making. Management Decision. Https://Doi.Org/10.1108/00251741211227663

Wahyono, W. (2018). Hubungan Motivasi Berprestasi dan Lingkungan Kerja dengan Kepuasan Kerja Dosen di Politeknik LP3I Jakarta. Jurnal Lentera Bisnis. Https://Doi.Org/10.34127/Jrlab.V6i2.179

Yagyagil, M. (2015). Article Information: Constructing a Typology of Culture in

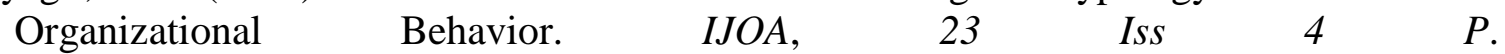
Https://Doi.Org/Http://Dx.Doi.Org/10.1108/IJOA-03-2013-0650 Downloaded

Zachary, L. (2017). Creating a Mentoring Culture The Organization Guide (First Edit; John Willey, Ed.). Https://Doi.Org/6583-124 